Instructions for authors, subscriptions and further details:

http://generos.hipatiapress.com

\title{
Education and Training: Advantaging the Level of Women's Legislative Participation in Kenya.
}

Mokua Ombati $^{1}$

1) Moi University, Kenya.

Date of publication: October $25^{\text {th }}, 2017$

Edition period: October 2017 - February 2018

To cite this article: Ombati, M. (2017). Education and Training: Advantaging the Level of Women's Legislative Participation in Kenya. Multidisciplinary Journal of Gender Studies, 6(3), 1463-1482. doi: 10.4471/generos.2017.2754

To link this article: $\mathrm{http}: / / d x . d o i . o r g / 10.4471 /$ generos.2017.2754

\section{PLEASE SCROLL DOWN FOR ARTICLE}

The terms and conditions of use are related to the Open Journal System and

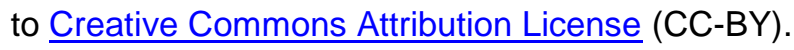




\title{
Education and Training: Advantaging the Level of Women's Legislative Participation in Kenya
}

\author{
Mokua Ombati \\ Moi University
}

\section{Abstract}

This study examines data on the patterns, nature and extent of women's legislative representation in Kenya and considers the role of education in increasing their participation. The main objective is to determine the status of women within the legislative assembly since Kenya gained independence in 1963 and explore the link between legislative representation, gender, and educational level and achievement. The study attempts to answer the question: Does education and training encourage women's legislative participation? It concludes that more gender equality in education and training increases the chances of women participation in legislative leadership positions in Kenya.

Keywords: women, education, training, legislative leadership, Kenya 


\title{
Educación y Formación: Favoreciendo el Nivel de Participación Legislativa de las Mujeres en Kenia
}

\author{
Mokua Ombati \\ Moi University
}

\section{Resumen}

Este estudio analiza los datos existentes sobre los patrones, la naturaleza y el alcance de la representación legislativa de las mujeres en Kenia y considera el papel de la educación para aumentar su participación. El objetivo principal es determinar la evolución de la representación de género en la asamblea legislativa desde que Kenia obtuvo la independencia en 1963 y explorar el vínculo entre la representación legislativa, el género y el nivel educativo y el rendimiento. El estudio intenta responder a la pregunta: ¿la educación y la formación fomentan la participación legislativa de las mujeres? Concluye que una mayor igualdad de género en la educación y la formación hace aumentar las posibilidades de participación de la mujer en posiciones de liderazgo legislativo en Kenia.

Palabras clave: mujer, educación, formación, liderazgo legislativo, Kenia 


\section{Ombati-Education and Training}

ood governance requires a more equitable representation of women in decision-making bodies, including in legislative assemblies, so as to more accurately reflect the composition of society and to ensure that women's diverse interests are taken into account. A greater proportion of women legislators will redefine "political priorities, placing new items on the political agenda that reflect and address women's gender specific concerns" (Mitullah, 2003, p. 219). Equally, good governance would comprise making and implementing policies for women and families among top legislative priorities (Hawkesworthy, 2006). However, masculinity pervades every area of life, and more than any other kind of human activity, politics has historically been more exclusively, intensely and self-consciously limited to men (Abigail, 2003). Thomas and Wilcox (2005) point out that the gender inequality that keep women at a disadvantaged position hinders their contribution on issues such as access to food, water, education, healthcare and all that matters to them most.

Even though women make up 52 percent of Kenya's population (KNBS, 2010), their participation in the electoral process does not reflect this demographic reality. They have largely played a marginal role in Kenya's political life since the country gained independence from Britain in 1963. Their performance for legislative elective office has been notably dismal. They have always been significantly under-registered and formed only 47.1 percent of the voter register in 2008 (IED, 2008). The first woman legislator and the first East African woman to serve as Councillor, Grace Monica Aketch Onyango, was elected into the council and parliament in 1964 and 1969 respectively. During Kenya African National Union (KANU) single party regime (1963-2002), only nine women managed to serve as legislators (WSP, 2008). Indeed FIDA-Kenya (2013, p. 2) notes that "between 1963 and 2012, Kenyan voters elected only 50 women to Parliament; indeed, this figure is actually lower as it includes those who were re-elected."

Though women are still disadvantaged and their numbers are comparatively lower than those of men, there has been a notable increase of women participation in legislative leadership since the beginning of transition politics in 1992. During the 2002 parliamentary elections there were only 44 (22 percent) women out of a total 1,015 parliamentary contenders (Nzomo, 2003). This translated to a ratio of 4 women to 96 men 
(Mitullah, 2003). Nine of the women contestants were elected while various parties nominated nine more to make the total number of women in the ninth parliament to rise to a high of eighteen (18), out of 222 legislators.

Women turned in large numbers to be elected during the 2007 general elections. Of the 2,548 parliamentary contenders, 269 women representing 10.6 percent contested Kenya's 210 parliamentary seats. The performance of women during the 2007 general elections was slightly higher than the 2002 elections, with sixteen (16) women being elected. However, taking into account the number of women candidates in 2007 as compared to 2002 , women did not perform as well as expected. In 2007, 5.6 percent of the women candidates made it to parliament while 20.4 percent succeeded in 2002. The good news is that the number of elected women parliamentarians increased from 4.2 per cent in the 9th parliament (20022007) to 7.1 per cent in the 10th parliament [2008-2013] (FIDA-Kenya, 2010; Kwamboka, 2008).

However, women accounted for only 9.8 percent of the total number of legislators in the 10th parliament, of whom 7.1 percent were elected and 2.7 percent nominated. This was a slight improvement from the 9 th parliament in which women consisted of 8 percent of legislators, where 4.2 percent were elected and 3.8 nominated. This proportion of women legislators still fell short of the United Nations target of achieving 30 percent representations of women in politics, and ranked Kenya number 101 as at May 2nd 2016 in IPU's world classification of women in national parliaments. Kenya ranked not only below the world average for women in parliaments at 19 percent but also below all countries in the East African region (IPU, 2016).

The progressive but gradual increase of women into the Kenyan legislature meant that without some kind of affirmative action mechanisms (Mokua, 2014a), such as gender quotas, the attainment of 30 per cent threshold remained elusive. Thus, women would continuously fail to make critical impacts on governance. The period after the 2007/2008 postelection conflict provided a unique opportunity for institutional and constitutional reform processes in a way that would have increased the opportunities for women to participate in decision-making. The conflict expanded opportunities for women and accompanying trends affecting their greater participation. 


\section{Ombati-Education and Training}

On that strength, the 2013 elections envisioned the greatest leap yet for women in elective and appointive leadership due to the promulgation of a new Constitution in 2010 (CoK, 2010). Indeed, the constitution went beyond spirit and rhetoric by making express provisions to secure effective representation of women, via the two-thirds gender principle, which provides that '...the State shall take legislative and other measures to implement the principle that not more than two-thirds of the members of elective or appointive bodies shall be of the same gender'(CoK, 2010, Article, 27[8]). Further, the Constitution expressly requires that 'the electoral system shall comply with the principle that - (b) not more than two-thirds of the members of elective public bodies shall be of the same gender' (CoK, 2010: Article 81). Together with this novel constitutional dispensation, aggressive institutional, legal, and electoral reforms in the lead to 2013 elections expanded electoral and political space that promised a turning point for women's legislative leadership in Kenya.

Unfortunately, the two-thirds principle suffered the greatest setback when the Supreme Court determined, in a ruling, that the principle was to be realized progressively and the requisite implementing law be passed by 2015 (which has not been realised by May 2017 when filing this manuscript). The Supreme Court effectively defeated the realization of the two-thirds principle at the national assembly and senate in the 2013 elections.

An analysis of the performance in the 2013 elections shows that out of the 2097 candidates (both men and women) who contested Kenya's 290 parliamentary constituencies, 1968 were male while 129 were women. 274 of the male candidates were elected representing 14 percent of those who vied and were elected, while 16 of the females were elected representing 12 percent of those who vied and were elected. These statistics indicate that 94 percent of the total aspirants were men while 6 percent were women. Equally, of those elected, 94 percent represented men, while 6 percent represented women.

Consequently, a gender composition of the 11th parliament (2013-2017) indicates a poor performance by women generally and women candidates in particular. The 11th parliament comprises a totality of 290 directly elected members from 290 constituencies. Forty seven (47) of these are women directly elected to represent each individual county. 16 women were 
directly elected from the single-member constituencies to account for only 6 percent of the directly elected members of the national assembly, which compares to 8 percent (16 women out of the 210 constituencies) of the 10th parliament. Out of the 12 members nominated by political parties, 5 women were nominated. Considering that the 10th Parliament had 6 nominated women, the number in the 11th parliament fell. Women representation at the county level was realized by the direct election of the 47 women representatives. Overall, with 68 women legislators in the 11th parliament, that translates into 19.4 percent of the total membership of the national assembly.

The situation is not any better in the senate. The Senate consists of 47 directly elected members from the 47 counties. No woman candidate was directly elected to the senate however 16 women were nominated to the reserved seats for women from party lists in proportion to the number of seats won by each political party. Another 2 women were nominated to represent youth and persons with disabilities making the total number of women in the Senate to be 18 , representing 27 percent of the senate membership.

Generally, the number of women legislators in the 11th parliament represents an improvement in that it is the highest number of women legislators in Kenyan history. However, the performance still falls short considering the constitutional provisions and the legal requirements that set aside various seats for women, as well as the selection of women to nominated seats, which was expected to lead to a more gender-balanced and gender-responsive house. Thus, despite an enabling constitution and legislation, women endured an inordinate number of hurdles and an environment void of political will, resulting in fewer than expected women competing and winning.

As these analyses indicate and, despite legal and constitutional provisions outlawing discrimination on the basis of gender, women continue to suffer setbacks whenever they seek not only elective, but also appointive positions. Mitullah and Owiti (2007, pp. 155-156) observe that "barriers to equal representation in decision-making bodies remain widespread despite better education and training" meaning that more gender equality in terms of participation in education has not resulted in more gender equality in other areas of political economy or socio-cultural 
relationships. It is on that note therefore, that this study examines the impact of education and training on women's legislative participation as a social group. Particularly, the study answers the question; how has education and training aided or disadvantaged women's level of ascendency to legislative leadership positions in Kenya?

\section{Theoretical Framework: Meritocratic Theory}

The study explains women's marginalization in legislative leadership positions in Kenya through the meritocratic theory. First coined by Michael Young (1958), meritocracy depicts a social system wherein appointments are made and responsibilities assigned to persons with the most ability, determined through explicit evaluations. Meritocracies make open, fair, just decisions, and extend opportunity further. Meritocratic equal opportunity policies are about standardizing practices, specifying and spelling out the requirements, reducing the role of tacit judgments and devising mechanisms, which ensure the enforcement of those rules, thus reducing prejudice.

Political careers do not have clearly defined and established qualifications (Norris \& Lovenduski, 1995), however, a meritocracy requires that whatever criteria and characteristics are required and employed do not exclude and marginalize particular groups. Meritocracy is presumed to rest upon timeless and unalterable ideals such as justice, social cohesion, progress, fairness and transparency, against which the imperfections of society should be judged. Correspondingly, "sentimental egalitarianism" and unfairness would only encourage mediocrity (Young, 1958, pp. 32-33), and "inequality of opportunity" fosters human inequality (Young, 1958, p. 85). Accordingly, a just society must be, amongst other things, be a meritocratic one. In a meritocracy the rule of the most qualified, is the primary mechanism, consideration, measure and principle, by which positions of responsibility are assigned. A meritocracy attracts numerous contestants in an open competition and those suitable are recruited by virtue of their merits in superior abilities, talents, efforts, qualifications and performance (Young, 2001). Criteria of measuring suitability are guided by formal, transparent, functionally specific and absolute principles of qualification, equity and performance, determined by objective, impersonal, externally validated, explicit and standardized rules of procedure and 
processes. This ensures that the most suitable candidate in terms of technical, educational, professional, experiential, psychological (personality), social, and politico-economic merits are recruited but not because of 'subjective' acceptability.

McNamee and Miller (2004) refer the gap between the meritocratic ideal and how society actually functions to as 'the meritocracy myth'. It is a myth because of the combined effects of non-merit factors which suppress, neutralize, or even negate merit and create barriers. In explaining the "invisible barriers that keep the upper echelons of society resolutely male," Nicholson (The Guardian, 24/06/2013) terms the "game of subtly but powerfully disadvantaging women the "false theory of meritocracy." This broken system of false meritocracy is bolted on to hierarchy, abetted by phony practices and controlled by men for men, even when it's not the optimum way of organising. A selection procedure based on other privileges and preferences, such as gender, patronage, ethnicity, social class and geographic location, violates the fundamental principles of meritocracy.

For the sake of strong and robust meritocratic ideals (Ansgar, 2011), society must challenge the conditions, which perpetuate inequality and marginalization. The knowledge that a system allows its members equal opportunities in an open competition is good for social stability. Glass (1954, p. 25) argues that the "existence of opportunity to rise in status" according to ability might lessen feelings "of personal frustration" and bring about "greater social harmony". It produces contentment or at least, it avoids discontent. When "the position of an individual" is no longer determined by 'impersonal forces,' "the attitude of the people towards their position in the social order necessarily changes" (Hayek, 1944, p. 79).

When women encounter exclusion, discrimination and prejudice simply because they are female, their ability to develop self-assurance, selfconfidence and self-assertiveness is greatly punctured. This intensely influences their self-determination, liberation and empowerment. Narayan (2005) acknowledges that, more than anything else, self-confidence is the resource that most strongly predicts life satisfaction. People with high selfconfidence have feelings of empowerment. Empowerment ensures feelings of autonomy and competency, self-efficacy and optimism. "People's beliefs that they can produce desired effects by their actions influences the choices they make, their aspirations, level of effort and perseverance, resilience to 


\section{Ombati-Education and Training}

adversity and vulnerability" (Bandura, 1998, p. 51). In short, their merits are greatly improved and harnessed for the individual and collective wellbeing.

How can society be made to operate more closely according to meritocratic principles that are collectively uniform to all? Meritocrats envision structures that would enable excluded people to find inclusion as well as to have happier, richer, more rewarding lives. Young (The Guardian, 29/06/2001) argues that, "involving local people and giving them training for national politics" would help in depolarising the meritocratic society. Nicholson (The Guardian, 24/06/2013) asserts that giving women a much better prospect for inclusive and collaborative leadership requires "decentralised, flat and team-based ways of organising" because they "are much more in tune with a globalised world than monolithic linear hierarchies. They also offer much better prospects for women leaders."

Acknowledging and advocating for the merits of women will pave way to their occupation of legislative leadership positions in large enough numbers. The assumption that it is only men who have the skills, capacities, competencies, resources, choices, capabilities, abilities and assets and therefore merit to be recruited into and be successful legislative leaders is to define formal suitability qualifications in a gendered way. The tendency to construct a single scale of gender measurement derived from and standardized on the basis of men's interpretations and data drawn from the males, tends to regard the male personality as the 'norm' and the female personality as some kind of deviation from the so called norm. Within all hierarchical institutions, leaders tend to hire, recruit, consult, and validate likeminded people whose appearance, background and abilities reflect their own pre-determined and prejudiced values of what successful leadership entails.

Traditionally, leadership in parliament and civic authorities has been a male-dominated field, thus not providing women any opportunities for mentorship. This not only disadvantages and excludes women, it also creates an environment where women are viewed (and view themselves) as 'not fitting in' with the common held perceptions on leadership, power and authority. In this way, patriarchal systems replicate themselves, sustaining the existence of the old boys club. A meritocracy underpins the central role of meritocratic principles as the primary baseline of recruitment. 
Consequently, the study examines merit and non-meritocratic aspects related to education and training that have been used to justify, sanction, subject and promote bias towards women seeking legislative leadership positions in Kenya.

\section{Qualitative Methodological Research Design}

This manuscript is a partial product of a research undertaken in partial fulfilment of the requirements for the Master of Arts degree submitted to Moi University, Kenya. Data for the study was derived from both documented literature and field research. The study assumed a qualitative research design out of its superior quality in having a deeper understanding of social phenomenon (Bryman, 2007). In addition, as Miles and Huberman (1994, p. 1) contend, "words, especially organised incidents or stories have a concrete, vivid, meaningful flavour that often proves far convincing than pages of summarized numbers."

Accordingly, a convenient sample of twelve (12) case-experience female legislative leaders was selected for in-depth interviews. The twelve respondents were clustered into three distinct but interrelated groups of: a) four current elected female legislators, b) four former elected female legislators, and c) four aspiring female legislative candidates who have previously vied but are yet to win a seat, but from constituencies, which the first two groups of cluster of respondents had not been selected. Nominated and other female legislators who earned their status by other means like gender quotas and/or reserved seats, without competing in an open contest were excluded from the sample.

The sample generated homogenous cases but diverse enough in characteristics to allow for enough comparisons and generalizations that were considered typically valid for the entire country. Examining the status of women as a distinct group and a comparative analysis of women in legislative leadership in Kenya and across countries, over time, provided the context and frame of reference upon which data was collected and subsequent conclusions drawn. The collected data was updated after the 2013 parliamentary elections.

All interviews were audio taped. A thematic analysis and patterning of the data was done involving editing, classifying, transcribing and coding. Final data analysis involved data reduction, interpretation and description 
through a process of discussion, reference and argument. Together with obtaining official authorizations for conducting research, the ethical and moral principles of conducting research were assiduously observed. Finally, the results as presented are in aggregate and/or by the use of pseudonyms to protect the identity of the respondents, constituencies and geographical settings.

\section{Education and Training for Women's Legislative Leadership}

Throughout Kenyan history, women have played an integral role in local leadership both inherited and elected for generations though they have had difficulty breaking into mainstream legislative leadership. Colonialism served to undermine African women's status in society and restricted them to the domestic, private sphere (Gordon, 1996). Historically, women received little or no education because neither African nor colonial patriarchs regarded it as important for women. Quoted in Mokua (2014b, p. 74), Courville provides a brief summary of the situation of African women in colonial times:

...under colonialism many African women were raped into submission, were exploited as labourers and endured subhuman status as slaves of colonial European and African patriarchal oppression and capitalistic expatiation.... The coexistence of dual political systems, dual patriarchal systems and dual modes of production shaped the exploitation and oppression experienced by African women.

In the colonial era, women in Kenya, as elsewhere in the African continent, were largely excluded from participation in modern education and employment. For example, at the end of World War II, boys had four secondary schools in Kenya: Alliance, Mangu, Maseno and St. Mary's Yala. There were no secondary schools in existence for girls (Bogonko, 1992). According to the missionaries who are credited for pioneering the establishment of western education in Kenya, as in other parts of Africa, men were required to go to school and be employed because they were expected to be providers to their families. The established legacy on 
discrimination against women in education and therefore employment, on account of their sex has not been easy to overcome:

The sex role distinctions common to many African societies supported the notion that western education was a barrier to a woman's role as a wife and mother, and an impediment to her success in these traditional modes of acquiring status. With few exceptions, girls were kept away from formal and especially higher education. The colonial administrations were therefore willing accomplices because they imported a view of the world in which women were of secondary importance. Clearly then, European colonialism, as well as traditional attitudes of and to women, combined to exclude African women from an educational process... (Davies, 1986, quoted in Mokua, 2014b, p. 75).

The consistent marginalisation of women in education has meant that women lack the competitive advantages associated with education to be able to effectively participate in legislative leadership positions in Kenya. According to Mokua (2013):

The returns of educating girls include...enhancement of women's...political participation (p. 111). Education enables women to acquire the skills needed for job entry, improves chances of vertical mobility, and enhances overall labour market productivity. The longer a girl is able to stay in school, the greater her chances to pursue worthwhile employment, higher education, and a life without the hazards of extreme poverty. Educated women are essential to ending gender bias, starting by reducing the poverty that makes discrimination even worse in Kenya as is the case in most developing countries. Education opens up opportunities for better-paying jobs for women (p. 113).

The educationally disadvantaged are marginalized and are increasingly less likely to be strong partisans, interested in politics, or following the news, all of which are related to political participation. Researching women in legislative leadership positions in Kenya, Mokua (2014b) quotes a female responded, wondering aloud, "Are we being fair when we put an educational qualification threshold on women wanting to join leadership, 


\section{Ombati-Education and Training}

equal to that of men when we know that while men were going to school women were not provided with that opportunity?" Another responded, categorically seethed, "Why are women candidates strictly catechized on the quality of their delivery, outcomes and representativity based on academic and educational qualifications, whereas the question of qualifications should be applied equally rigorously to men. Double standards? I don't understand!"

The educational discrimination concerns of the respondents, is compounded by the fact that in remote and inaccessible rural areas of Kenya, parents are unwilling to send girls to school if they are in danger of being kidnapped, raped, molested and subjected to other forms of abuse (Mokua, 2013). These causes delay enrolment of girls if security structures are not established. Often late enrolment is particularly damaging as girls reach adolescence and puberty while still in school. Mature girls are likely to become pregnant, resulting in public stigmatization, ridicule, loss of selfesteem and termination of studies (Ombati \& Mokua, 2012). Wamahiu (1995) notes that in such educational systems, girls lose in terms of educational attainment, skill acquisition and chance for employment opportunities. Mokua (2014b) agrees that women's marginalization in education and training has great bearing to their participation in legislative leadership. A respondent in Mokua's study (2014b, p.76) sums it thus:

...It's very difficult for women to talk, to argue, to press for their concerns. How can we encourage women to talk and express themselves? We have to encourage them to talk, not only about politics, but also about all of their problems, the life issues that concern them. The answer is education. Education can lead many women to join political parties or participate in political activities. Education is the most important channel for encouraging women to speak out. This can be done by giving women access, from an early stage, to knowledge patterns that are conducive to political leadership, such as special training in leadership and governance.

Education is more than just certificates; it is the fuel that runs humanity, it is inspiration, it is courage and confidence. An education does more than liberate people from poverty; it is the foundation of social and economic progress. Education provides attitudes and skills, contributes to society 
through demonstrated values, and the emergence of a more equitable, dynamic, and prosperous society. Education yields significant dividends in preparing the youth for a life of citizenship. Education has been touted (Mokua, 2014b) as an experience that truly facilitates, informs and motivates political involvement. Education not only provides a strong flow of information but also fosters the development of cognitive tools that facilitate this information to help nurture and incorporate a political ideological identity into the schemata of the individual (McDevitt, 2005).

Given that higher educational attainment is directly correlated to higher levels of health, prestige, wealth, access to human and institutional networks, higher labour market strata and employment opportunities, and ultimately power, a country with a high percentage of educated women will have a greater pool of qualified women to consider for legislative office (Mokua, 2014b, 2013; Ombati \& Mokua, 2012). Those women with higher levels of education have shown higher levels of both electoral and nonelectoral participation (Miller \& Shanks, 1996).

Writing on the benefits of higher education, Derek Bok (2013) views higher education as a pedestal to a better life, indicating that:

- Higher education affords graduates opportunity to find a middle-class job or better still high paying jobs and contribute to economic growth and prosperity.

- Higher education graduates seem to adapt more easily than those without as the economy evolves and labour-market needs change.

- Higher education graduates also vote at a higher rate, engage in more civic activities, commit fewer crimes, educate their children better and get sick less frequently by adopting healthier lifestyles.

Education adds to the acquisition of communication skills, increases the ability to process and incorporate higher quantities of more complex information, indoctrinates individuals into the process of learning and selfteaching, provides better reading skills and the ability to identify useful information, and a knowledge basis to develop greater understanding of new information and events (Moretti, Milligan \& Oreopoulos, 2004).

To be able to form an opinion and express it coherently, to show interest in affairs that transcend the immediate private sphere, to make political claims in public, are all instances of political conduct that presuppose an 
educated, motivated, and informed citizenry. Accordingly, an important factor that inhibits women's full and equal exercise of their right to compete for legislative office is their lack of knowledge and understanding of political systems or about the impact that political initiatives, processes and policies have upon their lives. Failure to understand the rights, responsibilities and opportunities for change conferred by franchise also means that few women offer their candidature for legislative office. The political parties, which are often men owned and controlled, exploit the political illiteracy of women. Poverty of political education shows itself in intolerance, bribery, intimidation, election rigging and politics with bitterness.

A respondent in Mokua's study (2014b, p. 77) categorically states the importance of having an educated and well-trained women-force:

We are going through a unique period in parliament where women have to learn for the first time, mostly by trial and error, how to carry parliamentary business. This calls for educating and training our women. Training is not only a means to ensure women have the vital skills required to carry out their jobs to the best of their ability, it is an essential part of any mentoring strategy and can help meet overall legislative 'pipeline' goals through a motivated and focused pool of woman-force.

Education then, creates a 'pipeline' group. Advancing through the pipeline would provide women with the experience, social-network connections and legitimacy necessary to seek legislative positions. The presence of a deep pool of qualified females to draw from offers the electorates more experienced and viable female candidates to recruit for legislative office a pool of eligible potential female candidates who have met the formal and informal requirements for election (Mokua, 2014b).

\section{The Study in Perspective}

This study has demonstrated the importance of education and training in explaining variation in women's legislative representation in Kenya. Education is an especially important variable, which determines and defines other variables. As Verba, Schlozman and Burns (2001, p. 110) contend, 
education is not simply "the single most potent predictor of an adult's political activity;" it is also "the engine for the transmission of political activity from generation to generation" (p. 98). This is important at two levels, educated parents are more likely to have educated children and they are more likely to provide a politically stimulating home environment. Educational attainment and parents' education level enhances confidence; it especially enhances a woman's odds of being politically active.

In addition, due to rapid social-economic changes as well as emergent needs of globalization, legislative leadership positions in Kenya, as in other countries, demand leaders who possess relevant sophisticated skills, knowledge and attitudes enhanced through experience. These appeals for formal and informal education and training. Education and training in governance and leadership, for example, is key for responsive, efficient and effective implementation of development programmes and in the conduct of legislative business.

Equally, of importance to note is that with increased penetration and access of the internet, more people and institutions are engaging social media as their tool for education, interaction and information dissemination. The amount of information generated through social media and the differential access that men and women have to services and opportunities is highly remarkable. Women therefore, need to be educated and be highly proficient in the use of social media.

Whichever indicator we look at, the impact of education is clear. Educated women are more likely to vote, to belong to a political party and to engage in legislative activities outside the traditional political arenas. They are also much more interested in politics and, not surprisingly, they are significantly better informed. Women with less education rank lowest on every dimension of political engagement, including non-electoral forms of political action.

\section{Conclusion}

That the government of Kenya has established constitutional, policies and legislation that promote gender equality in legislative leadership is not in doubt. However, the success of these initiatives remains minimal. The lack of political will to implement specific clauses is of particular concern. Worth noting is the two-thirds principle, which provides that '...the State 
shall take legislative and other measures to implement the principle that not more than two-thirds of the members of elective or appointive bodies shall be of the same gender' (CoK, 2010, Article 2[8]). For patriarchal procrastination therefore, Kenya continues to have the smallest number of women holding elective legislative office in the East African region, despite deliberate mechanisms to fast-track their levels and statuses.

The study has established that education is a clear contributing methodology and resource to participating in legislative leadership. Education enables one to advance in knowledge, technology, communication and other skills useful for public policy, debate, and direct training in political analysis. In addition, education provides the arena for early apprenticeship for politics, where young people exercise leadership, develop civic skills (e.g. on cooperation and negotiation), and expand their bureaucratic and organizational proficiencies.

Similarly, education and training are directly correlated to other factors supporting political engagement, such as access to higher-incomes and socio-economic statuses, which provide the resource-base for political activity, and access to political social networks, and contacts, which are fertile grounds for recruitment into political office. Equally, enhanced cognitive skills acquired in school are linked to subsequent performance in the labour economy. A more educated citizenry for example, translates into higher rates of diffusion of innovation, higher overall productivity and higher participation rates in leadership for marginalised groups. For those reasons, education and training advances the capacity of women to identify, articulate and defend their rights. These externalities provide extra reasons for concern about education and training for the womenfolk.

It is important to note therefore, that in spite of the early forms of disadvantage to the education and training of women, their limited participation in legislative leadership in Kenya is neither due to lack of qualifications, nor due to their restricted level of exposure and intellectual skills (merits). It is more a disregard of their merits than not. However, women's increased presence in legislatures alone will not guarantee change, but allow them to demonstrate sound political leadership, an awareness of women's needs and the importance of gender equality, all of which will open doors for the next generation of women leaders. 


\section{References}

Abigail, K. (2003). The participation of women in Kenya society. Nairobi: Kenya Literature Bureau.

Bogonko, S. N. (1992). A History of modern education in Kenya (18951991). Nairobi: Evan's Brother Ltd.

Burns, N., Schlozman, K. L., \& Verba S. (2001). The private roots of public action: Gender, equality, and political participation.

Cambridge, M. A.: Harvard University Press.

Constitution of Kenya (CoK). (2010). Published by the National Council for Law Reporting with the Authority of the Attorney General. Retrieved from www.kenyaconstitution.org $/ \mathrm{docs} / 03 \mathrm{~cd} / 005 / \mathrm{html}$.

Courville, C. (1993). Re-examining patriarchy as a mode of production: The case of Zimbabwe. In M. J. Stanlie \& P.A. B Abena (Eds.), Theorizing black feminisms: The visionary pragmatism of black women (pp. 31-43). London: Routledge.

Davies, B. C. (1986). Feminist consciousness and African literary criticism. In C. Boyce Davies \& G. Adams (Ed.), Ngambika: Studies of African women literature (pp. 1-24). Trenton, NJ: Africa World.

Derek, B. (2013, November 16). Higher education as means to a better life. Gulf News, Retrieved from www.gulfnews.com/opinions Gordon, A. (1996). Transforming capitalism and patriarchy: Gender and development in Africa. Boulder: Lynne Rienner.

FIDA-Kenya. (2013). Key gains and challenges: A gender audit of Kenya's 2013 election process. Nairobi, Kenya: Federation of Women Lawyers (FIDA).

FIDA-Kenya. (2010). Gender audit study of the $10^{\text {th }}$ parliament. Nairobi, Kenya: Federation of Women Lawyers (FIDA).

Hawkesworthy, M. E. (2006). Globalization and feminist activism.

Rowman and Littlefield: Lanham.

Inter-Parliamentary Union [IPU]. (2016). Percentage of women in each

National Parliament. Retrieved from http://www.ipu.org/wmne/classif.htm

Institute for Education in Democracy [IED]. (2008). Audit report on the registration of voters in 2007. Nairobi: IED

Kwamboka O. (2008, January 24). Kenya: Women Stood Up to Be Elected. The Daily Nation. 
Kenya National Bureau of Statistics [KNBS]. (2010). Kenya demographic and health survey 2008-2009. Nairobi, Kenya: Government of Kenya.

McDevitt, M. (2005). The partisan child: Developmental provocation as a model of political socialization. International Journal of Public Opinion Research, 18(1), 67-88. doi: https://doi.org/10.1093/ijpor/edh079

Miller, W.E. \& Shanks, J.M. (1996). The new American voter. Cambridge: Harvard University Press.

Mitullah, W. (2003). Gender inclusion in transition politics: A review and critique of women's engagement. In Walter O. Oyugi (Ed.), Politics of transition: From KANU to NARC (pp. 212-235). Nairobi, Kenya: Heinrich Böll Foundation.

Mokua, O. (2013). Educational gender party: Challenges of the Kenyan girl. Journal of Women's Entrepreneurship and Education, 3(4), 109125.

Mokua, O. (2014a). Regional Trends for Women's Electoral Success in the East African Legislatures. Journal of Women's Entrepreneurship and Education, 1(2), 153-172.

Mokua, O. (2014b). An assessment of the factors explaining the level of ascendency of women to legislative leadership positions in Kenya. Unpublished Master of Arts Thesis submitted to the School of Arts and Social Sciences, Department of Sociology and Psychology of Moi University, Kenya.

Moretti E., Milligan, K. \& Oreopoulos, P. (2004). Does education improve citizenship? Evidence from the U.S. and the U.K. Journal of Public Economics, 88(9\&10): 1667-1695. doi:

10.1016/j.jpubeco.2003.10.005

Nzomo, M. (2003). Taking stock of women's performance in Kenya's parliamentary politics in the 2002 general elections. In Perspectives on gender discourse: women in politics: Challenges of democratic transition in Kenya. Nairobi: Heinrich Böll Foundation.

Ombati \& Mokua. (2012). Gender inequality in education in Sub-Saharan Africa. Journal of Women's Entrepreneurship and Education, 3(4), 114-136. 
Ombati \& Mokua. (2015). Girl's education in Kenya's arid-semi arid zones. Cultura Crítica, Retrieved from

http://www.culturacritica.cc\%2F2015\%2F03\%2Fgirls-education-inkenyas-arid-semi-arid-zones

Thomas, S., \&Wilcox, C. (Eds.). (2005). Women and elective office.

Oxford: Oxford University Press.

Wamahiu, S. (Eds.). (1995). School dropout and adolescent pregnancy.

Nairobi: Forum for African Women Educationalists (FAWE).

WSP. (2008). The elusive quest for women's empowerment in electoral politics: A synopsis of the 2007 electoral year. Rapid assessment and gender audit of electoral processes in Kenya. (Raga II). Nairobi: WSP/HIVOS.

\section{Mr. Mokua Ombati}

\section{Contact address:}

Sociology and Psychology Department, Moi University.

P.O. Box 3900-30100, Eldoret (Kenya)

E-mail address: keombe@gmail.com 